\title{
Liudmyla Pashkevych ${ }^{1}$
}

\section{Effectiveness of Corruption Combating in Ukraine: Role of the System of Anti-Corruption Bodies}

\section{Introduction}

The phenomenon of corruption is possible in any society, because it is due to the peculiarities of human nature and the imperfection of government institutions. The recent history of mankind is a chronicle of the permanent fight against corruption - the illegal use by officials and politicians of their official opportunities for personal enrichment. Where corruption prevails, state power becomes the power of kleptocrats, which inevitably leads to social cataclysms, revolutionary upheavals, and where it is successfully countered, law and economic prosperity prevail. Examples of successful implementation of state programmes to combat this shameful phenomenon are the experience of the Baltic States, Poland, Georgia and others.

Despite the strong regulatory framework created to prevent and combat corruption, today it remains a systemic problem that exists at all levels of government in Ukraine. Despite the improvements observed in some areas, petty (domestic) and widespread corruption generally thrive. Political parties, the legislature, law enforcement, civil servants, and the judiciary are still perceived by citizens as highly corrupt institutions. At

1 Postgraduate Student, National Academy for Public Administration under the President of Ukraine, lyudmila_pashkevich@ukr.net, https://orcid.org/0000-0002-83403969. 
the same time, there is no general condemnation of corruption in society: almost a third of Ukrainian citizens believe that corruption can be justified, and bribery is a means of solving problems in relations with various government agencies as soon as possible. Given that the process of anti-corruption reform is underway in Ukraine, it is important to establish the institutional component of the fight against corruption, update anti-corruption legislation and establish specialized anti-corruption bodies.

Analysis of recent research and publications. The issue of creating a specialized anti-corruption body in our country and the use of foreign experience in the operation of such structures were considered by such scholars as: V. Hvozdets'kyy, R. Hrechanyuk, M. Hryshchenko, E. Dmytrenko, O. Dul's'kyy, O. Zhovnir, D. Zabroda, O. Kal'man, YU. Kasaraba, V. Kobryns'kyy, S. Konstantinov, B. Romanyuk, T. Chernyavs'ka and others.

The purpose of the article is to analyze the national experience of creation and functioning of specialized anti-corruption bodies with further improvement of the Ukrainian institutional model of preventing and combating corruption.

\section{Ukraine in the international anti-corruption movement}

Effective fight against corruption in Ukraine requires proper legislative support, the formation of an effective system of state bodies, ensuring proper coordination of the formation and implementation of anti-corruption policy, preventive measures to prevent corruption. The development of such an institutional system must meet international standards and international best practices.

Ukraine has joined the international anti-corruption movement by ratifying a number of international legal instruments and developing national anti-corruption legislation based on them. Civil society has recognized anti-corruption reform as the most urgent in our country, aimed at harmonizing anti-corruption legislation with international one, including European standards².

2 Yarmysh O. (2015) Spetsializovani antykoruptsiini instytutsii: svitovyi dosvid ta national'na model' [Specialized anti-corruption institutions: world experience and national 
Following Ukraine's ratification of the UN Convention against Corruption (2006) ${ }^{3}$, the Civil Convention against Corruption (1999) 4 and the Criminal Convention against Corruption in Ukraine (1999) of introducing anti-corruption legislation and creating a system of specialized anti-corruption bodies responsible for various aspects of state and anti-corruption policy, including anti-corruption.

\section{National Agency on Corruption Prevention}

With the adoption of the Law of Ukraine "Pro zapobihannia koruptsii" 6 ("About corruption prevention") in 2014, the leading role in the system of anti-corruption bodies was assigned to National Agency on Corruption Prevention ((hereinafter - National Agency) as a focal point of anticorruption policy in the state and a body with preventive anti-corruption functions.

National Agency, as a central executive body with a special status, ensures the formation and implementation of state anti-corruption policy and is accountable to the Verkhovna Rada of Ukraine and under the control and accountability of the Cabinet of Ministers of Ukraine ${ }^{7}$.

The special status of National Agency as a collegial body consisting of five members, due to the need to protect it from influence and interfer-

model]. Scientific Journal of the National Academy of Prosecutors of Ukraine. No. 2. Retrieved from: //www.chasopysnapu.gp.gov.ua/chasopys/ua/pdf/6-2015/yarmysh.pdf.

3 Konventsiia OON proty koruptsii, pryinyata na 58 sesii Heneral'noi Asamblei OON 31.10.2003 [UN Convention against Corruption, adopted at the 58th session of the UN General Assembly on October 31, 2003] (ratified by the Law of Ukraine No. 251-V (2006). Retrieved from: https://zakon.rada.gov.ua/laws/show/995_c16\# Text.

4 Tsyvil'na konventsiia pro borot'bu z koruptsiieiu, pidpysana u Strasburzi 04.11.1999 [Civil Convention against Corruption, Strasbourg, November 4, 1999] (ratified by the Law of Ukraine No. 2476-IV (2005). Retrieved from: https://zakon.rada.gov. ua/laws/show/994102\# Text.

5 Kryminal'na konventsiia pro borot'bu z koruptsiieiu, pidpysana u Strasburzi 27.01.1999 [Criminal Convention against Corruption, Strasbourg, January 27, 1999] (ratified by the Law of Ukraine No. 252-V (2006). Retrieved from: https://zakon.rada. gov.ua/laws/show/994_101\#Text.

6 Pro zapobihannia koruptsii [About corruption prevention]. No. 1700-VII (2014). Retrieved from: https://zakon.rada.gov.ua/laws/show/ 1700-18\#Text.

7 Ibidem. 
ence in its activities. This is achieved through the following components: a special procedure for the selection, appointment and termination of powers of members of National Agency; a special procedure for financing and logistical support of National Agency established by law; appropriate conditions for remuneration of members and the staff of National Agency; transparency of its activities.

Unlike other institutions that make up the state system of anti-corruption bodies - National Anti-Corruption Bureau of Ukraine, Specialized Anti-Corruption Prosecutor's Office and other law enforcement agencies that detect and investigate corruption crimes, the main function of National Agency is to prevent these crimes. This goal is achieved through the identification and elimination of factors that allow the commission of corruption offenses, monitoring compliance with anti-corruption rules by political parties, officials and politicians, working with whistleblowers and more.

The activities of National Agency are subject to public control, which is provided by the Public Council of the National Agency, that is formed by the Cabinet of Ministers of Ukraine from 15 people based on the results of the competition.

The main powers of National Agency are:

- analysis of the situation with corruption in Ukraine and development on its basis of the Anti-Corruption Strategy and the state program for its implementation, monitoring their implementation;

- detection of corruption norms in legislation and draft acts;

- control over observance of rules of ethical conduct, legislation on prevention of conflict of interests in activity of public servants;

- coordination and provision of methodological assistance to state bodies and local self-government bodies in identifying and eliminating corruption risks in their activities, coordination and control of the implementation of anti-corruption programmes in these bodies;

- control and verification of declarations of public servants, monitoring of their way of life, maintenance of the Unified State Register of such declarations;

- state control over observance of restrictions on financing of political parties, legal and targeted use of funds allocated from the state budget by parties, timeliness of submission of relevant reports by 
parties and accuracy of information included in them, approval of distribution of funds allocated from state budget to finance statutory activities of political parties;

- cooperation with whistleblowers, their legal and other protection;

- informing the public about the measures taken by the National Agency to prevent corruption, as well as involving them in the formation, implementation and monitoring of anti-corruption policy ${ }^{8}$.

\section{National Anti-Corruption Bureau of Ukraine}

In addition to National Agency, National Anti-Corruption Bureau of Ukraine is a specially authorized entity in the field of anti-corruption, which operates in accordance with the Law of Ukraine "Pro Natsional'ne antykoruptsiine biuro Ukrainy"9 (About National Anti-Corruption Bureau of Ukraine) adopted by the Verkhovna Rada of Ukraine on October 14, 2014.

National Anti-Corruption Bureau of Ukraine (abbr. - NABU) is a state law enforcement body that investigates and discloses corruption offenses by senior officials authorized to perform state or local government functions; carries out a pre-trial investigation of a crime committed by an official, if the damage caused or the subject of the crime is equal to or exceeds the amount of five hundred minimum wages established on the day of the crime; crimes committed against officials of foreign states, foreign arbitrators, persons authorized to resolve civil, commercial or labor disputes in foreign states in an alternative court procedure, officials of international organizations, as well as members of international parliamentary assemblies to which Ukraine is a party, and judges and officials of international courts, which are provided by Article 369 of the Criminal Code of Ukraine (abbr. - CCU) (offer, promise or illegal benefit to an official) and Article 3693 of CCU (abuse of influence) ${ }^{10}$.

8 Pro zapobihannia koruptsii [About corruption prevention]. No. 1700-VII (2014). Retrieved from: https://zakon.rada.gov.ua/laws/show/ 1700-18\#Text.

9 Pro Natsional'ne antykoruptsiine biuro Ukrainy [About National Anti-Corruption Bureau of Ukraine]. No. 1698-VII. (2014). Retrieved from: https://zakon.rada.gov.ua/ laws/show/1698-18\#Text.

10 Kryminal'nyi kodeks Ukrainy [Criminal Code of Ukraine]. No. 2341-III (2001). Retrieved from: https://zakon.rada.gov.ua/laws/show/ 2341-14\#Text. 
Thus, the main function of NABU is to combat corruption offenses committed by high-ranking officials and pose a threat to Ukraine's national security.

The NABU ${ }^{11}$ is responsible for the following crimes:

- misappropriation, misappropriation of property or taking possession of it by abuse of office (Article 191 of CCU);

- illegal seizure of property of an enterprise, institution, organization (Article 20 b2 of CCU);

- legalization (laundering) of proceeds from crime (Article 209 of CCU);

- misuse of budget funds, budget expenditures or granting loans from the budget without established budget allocations or with their excess (Article 210 of CCU) bribery of an employee of an enterprise, institution or organization (for employees of legal entities under public law (Article 354 of CCU);

- abuse of power or official position (Article 364 of CCU);

- declaring unreliable information (Article 366i of CCU);

- acceptance of an offer, promise or receipt of illegal benefit by an official (Article 368 of CCU);

- illegal enrichment (Article 3682 of CCU);

- offer, promise or provision of illegal benefit to an official (Article 369 of CCU);

- abuse of influence (Article 3692 of CCU);

- theft, misappropriation, extortion of weapons, ammunition, explosives or other weapons, vehicles, military and special equipment or other military property, as well as their acquisition by fraud or abuse of office (Article 410 of CCU) (Part 5 Article 21 b of CPC of Ukraine) ${ }^{12}$.

NABU detectives may also investigate crimes under the jurisdiction of investigators of other bodies in order to prevent, detect, stop and disclose crimes under its jurisdiction, by decision of the Director of National

11 Pro Natsional'ne antykoruptsiine biuro Ukrainy [About National Anti-Corruption Bureau of Ukraine]. No. 1698-VII. (2014). Retrieved from: https://zakon.rada.gov.ua/ laws/show/1698-18\#Text.

12 Kryminal'nyi kodeks Ukrainy [Criminal Code of Ukraine]. No. 2341-III (2001). Retrieved from: https://zakon.rada.gov.ua/laws/show/ 2341-14\#Text. 
Anti-Corruption Bureau of Ukraine and in agreement with Prosecutor of Specialized Anti-Corruption Prosecutor's Office ${ }^{13}$.

\section{Specialized Anti-Corruption Prosecutor's Office}

To ensure the independence of National Anti-Corruption Bureau of Ukraine, the investigation conducted by NABU detectives is supervised by employees of Specialized Anti-Corruption Prosecutor's Office (abbr. - SAP).

The legal basis for the establishment and operation of Specialized Anti-Corruption Prosecutor's Office was the Law of Ukraine "Pro vnesennia zmin do deiakykh zakonodavchykh aktiv Ukrainy shchodo zabezpechennia diial'nosti Natsional'noho antykoruptsiinoho biuro Ukrainy ta Natsional'noho ahentstva z pytan' zapobihannia koruptsii" adopted on February 12, 2015, which made changes to the Law of Ukraine "Pro prokuraturu" (About the Prosecutor's Office), in accordance with the provisions of which the General Prosecutor's Office of Ukraine established the SAP ${ }^{14}$.

Specialized Anti-Corruption Prosecutor's Office is an independent structural subdivision of the General Prosecutor's Office of Ukraine tasked with overseeing compliance with the law during the pre-trial investigation of National Anti-Corruption Bureau of Ukraine, supporting public prosecution in relevant proceedings, and representing citizens or the state. In cases provided by law and related to corruption or corruption-related offenses ${ }^{15}$.

13 Natsional'ne ahentstvo z pytan' zapobihannia koruptsii (2016). Pravovi zasady ta praktychni aspekty zapobihannia koruptsii: lektsiini materialy do treninhovoho navchal'noho kursu. [National Agency on Corruption Prevention (2016). Legal bases and practical aspects of corruption prevention: lecture materials for the training course]. Kyiv. Retrieved from: https://dabi.gov.ua/wp-content/uploads/2016/10/Pravovi-zasadyta-praktychni-aspekty-zapobigannya-koruptsiyi.pdf.

14 Pro prokuraturu [About the Prosecutor's Office]. No. 1697-VII (2014). Retrieved from: https://zakon.rada.gov.ua/laws/show/ 1697-18\#Text.

15 Yarmysh O. (2015) Spetsializovani antykoruptsiini instytutsii: svitovyi dosvid ta national'na model' [Specialized anti-corruption institutions: world experience and national model]. Scientific Journal of the National Academy of Prosecutors of Ukraine. No. 2. Retrieved from: //www.chasopysnapu.gp.gov.ua/chasopys/ua/pdf/6-2015/yarmysh.pdf. 
The general structure of Specialized Anti-Corruption Prosecutor's Office includes the central office and territorial branches located in the same cities as the territorial offices of National Anti-Corruption Bureau of Ukraine.

The Law of Ukraine "Pro prokuraturu" (About the Prosecutor's Office) establishes the legal basis for the organization of the SAP, as well as ensures the transparency of the competition commission for the appointment of administrative and prosecutorial positions in the SAP ${ }^{16}$.

Thus, appointments to administrative positions and prosecutors of the SAP are made by the head of the SAP based on the results of an open competition. Appointment to the positions of the Deputy Prosecutor General of Ukraine - the head of the SAP and the deputy heads of the SAP - is carried out by the Prosecutor General of Ukraine ${ }^{17}$.

\section{National Bureau of Investigation}

On March 1, 2016, the Law of Ukraine "Pro Derzhavne biuro rozsliduvan'" (About National Bureau of Investigation) came into force, according to which National Bureau of Investigation (abbr. - DBR) is the central executive body that will carry out law enforcement activities to prevent, detect, stop, detect and investigate crimes committed senior officials authorized to perform the functions of the state or local governments; officials of National Anti-Corruption Bureau of Ukraine, Deputy Prosecutor General of Ukraine - Head of Specialized Anti-Corruption Prosecutor's Office or other prosecutors of Specialized Anti-Corruption Prosecutor's Office, except when pre-trial investigation of these crimes is under the jurisdiction of detectives ${ }^{18}$ (Pro Derzhavne biuro rozsliduvan', 2016). Military service (war crimes), except for crimes under Article 422 of the CCU (disclosure of information of a military nature that consti-

16 Pro prokuraturu [About the Prosecutor's Office]. No. 1697-VII (2014). Retrieved from: https://zakon.rada.gov.ua/laws/show/ 1697-18\#Text.

17 Pro prokuraturu [About the Prosecutor's Office]. No. 1697-VII (2014). Retrieved from: https://zakon.rada.gov.ua/laws/show/ 1697-18\#Text.

18 Pro Derzhavne biuro rozsliduvan' [About National Bureau of Investigation]. No. 794-VIII (2015). URL: https://zakon.rada.gov.ua/laws/show/ 794-19\#Text. 
tutes a state secret, or loss of documents or materials containing such information).

The establishment of National Agency of Ukraine for finding, tracing and management of assets derived from corruption and other crimes is one of the requirements of EU's in the framework of the Action Plan on Visa Liberalization and Ukraine's further accession to the EU.

In 2018, the process of adjusting the work of the Bureau continued, according to the results of competitions, more than 500 employees joined the organization, of which 285 - as investigators. A regional network was also built - territorial DBR offices were opened in Kyiv, Kramatorsk, Lviv, Melitopol, Mykolayiv, Poltava, and Khmelnytsky, and their regulations and annual programs were approved ${ }^{19}$.

As of the end of 2019, National Bureau of Investigation, as a law enforcement agency, was conducting a pre-trial investigation of more than 2,400 criminal proceedings, of which 569 were initiated by the Bureau's investigators. 70 criminal proceedings were sent to court ${ }^{20}$.

\section{Asset Recovery and Management Agency}

The Law of Ukraine "Pro Natsional'ne ahentstvo Ukrainy z pytan' vyiavlennya, rozshuku ta upravlinnia aktyvamy" (About National Agency of Ukraine for finding, tracing and management of assets derived from corruption and other crimes) of November 10, 2015 № 772-1/111 defines the legal and organizational principles of the Agency's operation. In accordance with the provisions of the Law, National Agency of Ukraine for finding, tracing and management of assets derived from corruption and other crimes (abbr. - Asset Recovery and Management Agency or

19 Yarmysh O. (2015) Spetsializovani antykoruptsiini instytutsii: svitovyi dosvid ta national'na model' [Specialized anti-corruption institutions: world experience and national model]. Scientific Journal of the National Academy of Prosecutors of Ukraine. No. 2. Retrieved from: //www.chasopysnapu.gp.gov.ua/chasopys/ua/pdf/6-2015/yarmysh.pdf.

20 Natsional'ne ahentstvo z pytan' zapobihannia koruptsii (2016). Pravovi zasady ta praktychni aspekty zapobihannia koruptsii: lektsiini materialy do treninhovoho navchal'noho kursu. [National Agency on Corruption Prevention (2016). Legal bases and practical aspects of corruption prevention: lecture materials for the training course]. Kyiv. Retrieved from: https://dabi.gov.ua/wp-content/uploads/2016/10/Pravovi-zasadyta-praktychni-aspekty-zapobigannya-koruptsiyi.pdf. 
ARMA) is a central executive body of Ukraine with a special status that ensures the formation and implementation of state policy in identifying and investigating assets which is seized in criminal proceedings, and / or in the management of assets seized or confiscated in criminal proceedings ${ }^{21}$.

Thus, the establishment of the Asset Recovery and Management Agency enshrines at the legislative level the institutional mechanism for searching for assets to be seized, returned and managemented, as well as ensures the inevitability of punishment for criminal corruption crimes - deprives them of income from criminally acquired assets.

National Agency manages assets seized in criminal proceedings, including cash, bank metals, movable and immovable property, securities, property and other rights, the value of which is equal to or exceeds 200 times the minimum wage set for January 1 of the relevant year (Pro Natsional'ne ahentstvo Ukrainy z pytan' vyiavlennia, rozshuku ta upravlinnia aktyvamy, 2015: art. 19-21).

ARMA was established to address the problem of ineffective disclosure of assets obtained through crime and corruption. The establishment and launch of the Agency was one of the key requirements of the Visa Liberalization Action Plan in the framework of the visa-free dialogue between Ukraine and the EU.

During 2018, measures were taken to complete the process of ensuring the functional capacity of ARMA to perform the functions assigned to it to identify, search and manage assets. In particular, the central staff of the Agency was staffed, and six territorial offices were established ${ }^{22}$.

Last year, for the first time, a full-fledged process of managing the seized assets was carried out - from the acceptance into the manage-

21 Pro Natsional'ne ahentstvo Ukrainy z pytan' vyiavlennia, rozshuku ta upravlinnia aktyvamy, oderzhanymy vid koruptsiinykh ta inshykh zlochyniv: Zakon Ukrayiny [About National Agency of Ukraine for finding, tracing and management of assets derived from corruption and other crimes]. No. 772-VIII (2015). Retrieved from: https://zakon.rada. gov.ua/laws/show/772-19\#Text.

22 Pro Natsional'ne ahentstvo Ukrainy z pytan' vyiavlennia, rozshuku ta upravlinnia aktyvamy, oderzhanymy vid koruptsiinykh ta inshykh zlochyniv: Zakon Ukrayiny [About National Agency of Ukraine for finding, tracing and management of assets derived from corruption and other crimes]. No. 772-VIII (2015). Retrieved from: https://zakon.rada. gov.ua/laws/show/772-19\#Text. 
ment of ARMA to the return of these assets to their owner. Thus, various types of seized assets (real estate, vehicles, corporate rights) were transferred to the managers and the profitability of the management of these assets was ensured at a level that ensures their maintenance for further confiscation or return to the owners. By the end of the year, according to the work of ARMA, more than UAH 9 million was provided. revenues from the management of seized assets to the State Budget of Ukraine, and the sale of seized assets brought an additional UAH 3.1 million $^{23}$.

\section{Conclusions}

Institutional support, based on anti-corruption authorities, plays an important role in overcoming corruption in Ukraine. This system of bodies includes: National Agency on Corruption Prevention, National AntiCorruption Bureau of Ukraine, Specialized Anti-Corruption Prosecutor's Office, National Bureau of Investigation and National Agency of Ukraine for finding, tracing and management of assets derived from corruption and other crimes. National Agency on Corruption Prevention is a central executive body with a special status that ensures the formation and implementation of state anti-corruption policy. The main function of National Agency is to prevent the commission of corruption crimes. National Anti-Corruption Bureau of Ukraine is a state law enforcement body that deals with pre-trial investigation and disclosure of corruption offenses by senior officials authorized to perform state or local government functions. In the updated system of specially authorized entities in the field of anti-corruption, the Prosecutor's Office remains a key body, whose activities are characterized by multifunctionality and multifaceted, covering such areas as: prosecutorial oversight of a special anti-corruption body - NABU, which is implemented exclusively by Specialized Anti-Corruption Prosecutor's Office; crime; coordination

23 Natsional'ne ahentstvo z pytan' zapobihannia koruptsii (2016). Pravovi zasady ta praktychni aspekty zapobihannia koruptsii: lektsiini materialy do treninhovoho navchal'noho kursu. [National Agency on Corruption Prevention (2016). Legal bases and practical aspects of corruption prevention: lecture materials for the training course]. Kyiv. Retrieved from: https://dabi.gov.ua/wp-content/uploads/2016/10/Pravovi-zasadyta-praktychni-aspekty-zapobigannya-koruptsiyi.pdf. 
of the activities of these bodies in this area; pre-trial investigation of corruption crimes until the establishment of DBR. National Bureau of Investigation is a central executive body that carries out law enforcement activities in order to prevent, detect, stop, detect and investigate crimes committed by senior officials authorized to perform state or local government functions. National Agency of Ukraine for finding, tracing and management of assets derived from corruption and other crimes is a central executive body of Ukraine with a special status that ensures the formation and implementation of state policy in the field of detection and search of assets that may be seized criminal proceedings.

The above-mentioned bodies were created taking into account the European experience in the formation of anti-corruption bodies in the system of government, their activities are aimed at overcoming corruption in the country. Today, the legislative support for the formation of national system of anti-corruption bodies cannot be considered complete, as large-scale reforms of specially authorized entities in the field of anti-corruption are still underway. Corruption affects all spheres of social development and destroys the state system from the inside, so our state needs to ensure the independence of anti-corruption institutions and promote cooperation between these institutions.

\section{References}

Konventsiia OON proty koruptsii, pryinyata na 58 sesii Heneral'noi Asamblei OON 31.10.2003 [UN Convention against Corruption, adopted at the 58th session of the UN General Assembly on October 31, 2003] (ratified by the Law of Ukraine No. 251-V (2006). Retrieved from: https://zakon.rada.gov.ua/laws/show/995_c16\# Text.

Kryminal'na konventsiia pro borot'bu z koruptsiieiu, pidpysana u Strasburzi 27.01.1999 [Criminal Convention against Corruption, Strasbourg, January 27, 1999] (ratified by the Law of Ukraine No. 252-V (2006). Retrieved from: https://zakon.rada.gov.ua/laws/ show/994_101\#Text.

Kryminal'nyi kodeks Ukrainy [Criminal Code of Ukraine]. No. 2341-III (2001). Retrieved from: https://zakon.rada.gov.ua/laws/show/ 234114\#Text. 
Kryminal'nyi protsesual'nyi kodeks Ukrainy. [Criminal Procedure Code of Ukraine]. No. 4651-VI (2012). Retrieved from: https://zakon.rada.gov. ua/ laws/show/4651-17\#Text.

Natsional'ne ahentstvo z pytan' zapobihannia koruptsii (2016). Pravovi zasady ta praktychni aspekty zapobihannia koruptsii: lektsiini materialy do treninhovoho navchal'noho kursu. [National Agency on Corruption Prevention (2016). Legal bases and practical aspects of corruption prevention: lecture materials for the training course]. Kyiv. Retrieved from: https://dabi.gov.ua/wp-content/uploads/2016/10/ Pravovi-zasady-ta-praktychni-aspekty-zapobigannya-koruptsiyi.pdf.

Pro Derzhavne biuro rozsliduvan' [About National Bureau of Investigation]. No. 794-VIII (2015). URL: https://zakon.rada.gov.ua/laws/show/ 794-19\#Text.

Pro Natsional'ne ahentstvo Ukrainy z pytan' vyiavlennia, rozshuku ta upravlinnia aktyvamy, oderzhanymy vid koruptsiinykh ta inshykh zlochyniv: Zakon Ukrayiny [About National Agency of Ukraine for finding, tracing and management of assets derived from corruption and other crimes]. No. 772-VIII (2015). Retrieved from: https://zakon.rada. gov.ua/laws/show/772-19\#Text.

Pro Natsional'ne antykoruptsiine biuro Ukrainy [About National AntiCorruption Bureau of Ukraine]. No. 1698-VII. (2014). Retrieved from: https://zakon.rada.gov.ua/laws/show/1698-18\#Text.

Pro prokuraturu [About the Prosecutor's Office]. No. 1697-VII (2014). Retrieved from: https://zakon.rada.gov.ua/laws/show/ 1697-18\#Text. Pro zapobihannia koruptsii [About corruption prevention]. No. 1700-VII (2014). Retrieved from: https://zakon.rada.gov.ua/laws/show/ 170018\#Text.

Tsyvil'na konventsiia pro borot'bu z koruptsiieiu, pidpysana u Strasburzi 4.11.1999 [Civil Convention against Corruption, Strasbourg, November 4, 1999] (ratified by the Law of Ukraine No. 2476-IV (2005). Retrieved from: https://zakon.rada.gov.ua/laws/show/994102\# Text.

Yarmysh O. (2015) Spetsializovani antykoruptsiini instytutsii: svitovyi dosvid ta national'na model' [Specialized anti-corruption institutions: world experience and national model]. Scientific Journal of the National Academy of Prosecutors of Ukraine. No. 2. Retrieved from: //www. chasopysnapu.gp.gov.ua/chasopys/ua/pdf/6-2015/yarmysh.pdf. 


\section{Summary}

The aim of this paper is an analysis of the formation and functioning of the anti-corruption system of Ukraine: National Agency on Corruption Prevention, National Anti-Corruption Bureau of Ukraine, Specialized Anti-Corruption Prosecutor's Office, National Bureau of Investigation and National Agency of Ukraine for finding, tracing and management of assets derived from corruption and other crimes. The study stresses that despite the strong regulatory framework created to prevent and combat it, corruption remains a systemic problem that exists at all levels of government in Ukraine. The above-mentioned bodies have been created taking into account the European experience in the formation of anti-corruption bodies in the system of government, their activities are aimed at overcoming corruption in the country. The article highlights the feasibility of the existence and functioning of anti-corruption bodies and substantiates the importance of all their powers in the field of preventing and combating corruption. It has been concluded that these bodies need further improvement to combat corruption more effectively.

Keywords: corruption, specialized anti-corruption bodies, anti-corruption policy, corruption offenses, legislative support, standards 